УДК 782.1+782:784.21:784.25:784.95

DOI 10.31723/2524-0447-2018-26-63-74

\author{
Го Цяньпін \\ https://orcid.org/0000-0002-7601-4981 \\ здобувач кафедри історії музики \\ та музичної етнографії \\ ОНМА ім. А. В. Нежданової \\ odma_n@ukr.net
}

\title{
ВЗАЕМОДІЯ СЛОВЕСНИХ ЖАНРОВИХ ФОРМ В МУЗИЧНОМУ ТЕКСТІ ОПЕРИ (НА ПРИКЛАДІ ТВОРЧОСТІ М. МУСОРГСЬКОГО)
}

\begin{abstract}
Мета статті - відкрити значення публічно-словесних жанрових форм в розвитку музичної мови опери, виявити специфічні тенденції їх перетворення у музичному тексті опери. Методологія роботи базується на літературознавчих та музикознавчих підходах до вивчення мовно-комунікативних засобів, передбачає семіологічне поглиблення текстологічного музикознавчого аналізу. Наукова новизна дослідження обумовлена запровадженням нових жанрових та мовно-мовленнєвих критеріїв вивчення оперної мови, що дозволяють визначати синтетичні форми оперних сольно-вокальних лексикодів, зокрема у творчості М. Мусоргського. Висновки роботи вказують, по-перше, на провідне значення у розвитку оперної вокальної мови впливу жанрів словесності, пов'язаних з риторичною практикою та провідними комунікативними життєво-повсякденними сферами, по-друге, на ті новаторські досягнення М. Мусоргського, які позначили подальший розвиток музичної мови опери як синтетичної за сумісними зі словесними жанрами витоками.
\end{abstract}

Ключові слова: словесні жанрові форми, музичний текст опери, оперні сольно-вокальні лексикоди, усні та письмові форми слова, оперна творчість М. Мусоргського.

Guo Qianping, applicant of the Department of Music History and musical ethnography of Odessa National A. V. Nezhdanova Academy of Music

Interaction of worded genre forms in the musical text of opera (in the example of M. Musorgsky's creativity)

The purpose of the article is to discover the significance of public-verbal genre forms in the development of the musical language of the opera, to reveal the specific tendencies of their transformation in the musical text of the opera. The methodology of work is based on literary and musical approaches to the study of linguistic-communicative means, envisages a semioological deepening of textual musicological analysis. The scientific novelty of the research is due to the introduction of new genre and language-speech criteria for studying the operatic 
language, which allow determining the synthetic forms of operatic solo-vocal lexicons, in particular, in the work of M. Mussorgsky. The conclusions of the work indicate, firstly, that the leading role in the development of the operatic vocal language of the influence of literary genres, associated with rhetorical practice and the leading communicative life-spoken areas, in the second, on the innovative achievements of $M$. Mussorgsky, which marked the further development the musical language of the opera as a synthetic, compatible with verbal genres.

Keywords: verbal genre forms, musical text of opera, opera solo-vocal lexicodes, oral and written forms of the word, operatic creativity of M. Mussorgsky.

Го Цяньпин, соискатель кафедры истории музыки и музыкальной этнографии ОНМА им. А. В. Неждановой

Взаимодействие словесных жанровых форм в музыкального текста оперы (на примере твориества М. Мусоргского)

Цель статьи - открыть значение публично-словесных жанровых форм в развитии музыкального языка оперы, выявить специфические тенденции их преобразования в музыкальном тексте оперы. Методология работы базируется на литературоведческих и музыковедческих подходах к изучению культурно-коммуникативных средств, предусматривает семиологическое углубление текстологического музыковедческого анализа. Научная новизна исследования обусловлена введением новых жанровых и языково-речевых критериев изучения оперного язы$\kappa a$, позволяющих определять синтетические формы оперных сольно-вокальных лексикодив, в частности в творчестве М. Мусоргского. Выводы работы указывают, во-первых, на ведущее значение в развитии оперной вокальной речи влияния жканров словесности, связанных с риторической практикой и ведущими коммуникативными жкизненно-обиходными сферами, во-вторых, на те новаторские достижения М. Мусоргского, которые обозначили дальнейшее развитие музыкального языка оперы как синтетического по совместным со словесными жанрами истокам.

Ключевые слова: словесные жанровые формы, музыкальный текст оперы, оперные сольно-вокальные лексикоды, устные и письменные формы слова, оперное творчество М. Мусоргского.

Актуальність теми статті. Діалектика усної й письмової форм слова розкривається в музичному тексті опери в новому художньому значенні, стає опорним моментом, «несучою конструкцією» оперної семантики. Цей процес музичної актуалізації письмового поетичного слова та поетизації усного прозаїчного слова в оперному мелосі $є$ основою речитативно-оперних форм, які можна назвати найбільш значущими з боку взаємодії словесного та музичного планів опери.

Відомо, що у процесі свого історичного становлення музика завжди була тісно зв'язана зі словом, однак роль слова в музично- 
творчому процесі суттєво еволюціонує. Первинна синкретична єдність лого- і звукоформ поступилася місцем їх самостійному відособленому розвитку в якості художніх структур, котрі набувають якостей «літературності» і «музикальності». Література й музика пропонують різні шляхи художнього осмислення дійсності: перша спрямована до подійно-фактографічного виміру життєвих явищ і фіксованих раціональних понять, інша - до глибинного почуттєвого досвіду та його образного відбиття-означення. Проте названі мистецькі форми зберігають можливість зближення та взаємодії; література прагне до емоційного впливу, котрий не поступається музичному; музика досягає рівня логічної точності і строгості, мовної нормативності, що визнається як специфічно понятійна. У такий спосіб виникають передумови виправданого нового синтезу вербально-словесного та аудіально-музичного начал сприйняття дійсності.

Мета статті полягає у відкритті значення публічно-словесних жанрових форм в розвитку музичної мови опери, специфічних тенденцій їх перетворення у музичному тексті опери.

Основний зміст роботи. Звернення композиторів-романтиків до літературної творчості може мати багато пояснень. Однак композиторів романтичного періоду найбільше хвилювали питання про роздільність і єдність думок і почуттів людини, а у зв'язку з цим - питання про здатність музики їх втілювати. Інтимна сутність, інтимні механізми свідомості є таємничою сферою для людського пізнання. Мова музики, яка спрямована до їі відображення, також постає зашифрованою, такою, що уникає звичної предметно-поняттєвої визначеності. Для того щоб зробити ії зрозумілою, необхідне додаткове тлумачення - зазвичай в словесній формі, у якій переважає раціональна сторона логічних побудов, котра є загальноприйнятою.

При цьому словесне визначення спроможне набувати абстрактнометафоричної форми, адже воно служить своєрідним «перекладом» музичної ідеї. Літературно-критична форма висловлення композиторських поглядів, літературно оформлена або обумовлена концепція як необхідна частина музичного задуму, зближення засобів музичного впливу з літературними завдяки застосуванню прийомів, характерних для літературної форми, - ці рівні роботи зі словом у творчості західноєвропейських композиторів епохи романтизму виявляють принципову єдність і можуть бути визначені в цілому як основа творчого методу. 
Але суттєвим виявляється питання про те, які саме словесно-мовні жанри (як усні, повсякденні, так і письмові, літературно «оброблені») здатні впливати на розвиток оперних сольно-вокальних лексикодів, до яких належать речитатив, декламація, аріозний спів.

Певні «підказки» у розв’язанні цього питання виявляє лаконічне, але дуже ємне філологічне есе І. Чистякової, що містить спробу жанрової класифікації «мовної словесності» і почасти розвиває категорії первинних і вторинних жанрів у тій естетичній інтерпретації, яка була запропонована М. Бахтіним.

I. Чистякова будує хід власних міркувань на обговоренні того факту, що будь-яка мова оформляється в тексті у вигляді певного жанру, при цьому одні жанри спрямовані до дозвілля, розваги суспільства, інші - прямують до регулювання основних суспільних процесів, у тому числі у різних професійно-комунікативних галузях. До передумов розмежування мовних жанрів вона відносить традиційно-історичний або інноваційний характер, відокремлення публічно-риторичних жанрів від спеціалізовано-мовних, ознаки первинності або вторинності словесно-мовних текстів, явище міжжанрової взаємодії, нарешті усний і письмовий способи функціонування текстів.

За іiї словами, загальний порядок жанрів словесності передбачає множинні повтори: «стаття наукова і стаття публіцистична; доповідь в усній діловій мові і доповідь у дорадчій політичній ораториці; реклама в засобах масової комунікації й виборній політичній мові; нота в письмовій дипломатичній словесності та вербальна нота в дипломатичній ораториці як усний публічний жанр; молитва в письмовій духовній словесності і канонічна молитва в гомілетиці; повчання в сфері повсякденного спілкування та у духовній літературі; скарга в офіційно-діловій мові і скарга як первинний мовний жанр побутового спілкування; наказ в офіційно-діловій мові й вимога в повсякденному спілкуванні; дифірамб як ліричний літературно-художній жанр і дифірамб як первинний мовний жанр побутового спілкування» [7].

Особливо важливими в методичному відношенні уявляються ті висновки автора, які адресовані симбіотичним усно-письмовим жанровим формам. Її власними словами, «хотілося б особливо вказати на те, що, крім численних літературно-художніх жанрів в їх письмовому виконанні й усних жанрів фольклору, ми знаходимо в архіві російської словесності види, які мають і не мають опозиції - усні - письмові» [7]. Причому таку злитість комунікативних ознак Чистякова знаходить у так званих «родах словесності», до яких нею віднесені ді- 
лова, дипломатична, духовна «словесності» та засоби масової комунікації, що існує з публіцистикою «в одній фактурі мови».

Поняття «фактури мови» особливо привабливе в цьому випадку, оскільки також може бути сприйнятим як один із критеріїв розпізнавання дійсної природи жанру, його домінантної ознаки. Труднощі такого розпізнавання підсилюються тим, що всі словесні жанри мають здатність до інтертекстуальної трансляції своїх семантичних фігур: у певних випадках тема, ідея з одного виду словесності передається в інший і відбувається збагачення змісту, а зібрання всіх жанрів усної і письмової словесності не представлене в жодному сучасному або історичному джерелі, причому найбільш загадковою сферою тут залишаються види усного слова.

У сфері усного риторичного спілкування, до якого певною мірою відноситься і оперна умовна «словесність», особливо важко встановити первинність або вторинність жанру, тим більше, що «якщо жанри первинні, тобто жанри повсякденного спілкування, не раз були предметом вивчення М. М. Бахтіна, то жанри вторинні, тобто ті, що формуються в умовах організованого культурного спілкування, описані недостатньо» [7].

Одночасно з виявленням дискусійних моментів у визначенні мовних форм словесності автор виділяє родові форми усно-письмового слова, які допускають і первинні, і вторинні жанрові позиції, залежно від контексту їх використання. Як жанри-сюзерени (термінологія Д. Лихачова [2]), вони включають до свого складу низку жанрів-васалів, причому у відповідності до ситуації використання або спрямованості впливу, тобто в залежності від потреб як адресанта, так і адресата.

Це такі родові форми слова, як духовна словесність, епідейктична та національна ораторика. До духовної словесності відносяться притча, житіє, слово, повчання, заповідь, завіт, послання, молитва, гомілетичні жанри - проповідь, слово на Соборі, сповідь, псалтир, псалом, тропар, кондак, вигук, пісня ангельська, єктенія, славослів'я, канонічна молитва, повчання, читання, акафіст, бесіда. 3 наведеної низки жанрових номінацій очевидно, що навіть у філологічній класифікації вони включають вказівку на музичну форму.

Жанрову сферу епідейктичної ораторики представляють вітальна мова, ювілейна мова, урочиста мова, похвальне слово, ритуальна мова, вдячна мова, відповідне слово, мова на презентації, виступ із приводу пам'ятних дат, знаменних подій, свят. 
Національна ораторика складається як сукупність жанрів і жанрових форм, матеріальним вираженням яких стають ті зразки публічних мов, які історично склалися під впливом національно-культурних традицій і суспільного ідеалу, знайшли відбиття у свідомості народу, тому це і ті взірці, що реально існують у мовній компетенції носіїв мови [7].

Характеристики іманентної системної жанрової визначеності сфери словесної мови, які можна вивести з класифікації І. Чистякової, постають наступними: піднесення над повсякденністю, але таке, що зберігає безпосередній зв'язок з життєвою ситуацією, актуальною подією та живим людським характером; транзитивність щодо соціально важливих узагальнень та комунікативного досвіду; перейнятість риторичними інтонаціями, що переконують та моралізують; взаємодія з афектами, що створюють позитивні колективні уявлення, наділені відповідальністю за них.

Ці характеристики стають визначенням сполучних семантичних ланок між словесно-мовними формами та способами їх музичного втілення в опері. Вони дозволяють зрозуміти причини зацікавленості всіх названих родових форм усно-письмового слова в музичному перетворенні, сприяють визначенню передумов відокремлення та основних критеріїв семантичної типології оперного слова.

Підтвердження висунутої теоретичної гіпотези можна знайти шляхом стильового та композиційно-стилістичного аналізу оперних творів тих композиторів, зокрема російських, для яких вибір слова і прийомів його оперної презентації виступав необхідною частиною оперної реформи.

Так, у творчості М. Мусоргського провідне значення набувають словесно-мовні фактори інтонування із впливом буденного прозаїчного мовлення (до-літературного); композитор створює певну типологію вокалізованної мови як музичної, коли знаходить постійні характерологічні прийоми й визначає їх психологічний вплив. За спостереженням О. Оголевця, композитор пов'язує повільний темп мовлення з його переконливістю, заради якої слова вимовляються нібито в роздумі, розтягуються й виникає підкреслення окремих складів; у смутку й уболіванні людина також говорить повільно, мовби пригадуючи; з певним утрудненням виражаються емоційно-психологічні стани подиву, захоплення, серйозних визнань, спроби охопити багатозначні явища, ситуації, які можуть приводити до розгубленості. Не менший психологічний спектр і у швидкої мови - від хвилювання до 
розпачу; прискорення може відбуватися імпульсивно, чергуватися 3 уповільненням, демонструючи критичні стани свідомості і т. д. [4].

Дослідження О. Оголевця, присвячене питанням спорідненості і відмінностей структури та функцій слова й музики у вокально-драматичних жанрах, до сьогоднішнього дня залишається класичним. Разом з тим мало хто з музикознавців звертає увагу на те, що, по-перше, Оголевець поєднує розвиток словесно-мовних факторів інтонування із впливом саме буденної прозаїчної мови (до-літературної), підкреслюючи значення життєвих умов, жанрових зв'язків музики з повсякденним світом людських відносин; по-друге, він створює певну типологію вокалізованної мови як музичної, коли знаходить постійні характерологічні прийоми (і визначає цілісність їх психологічного впливу).

Естетична позиція М. Мусоргського цілком грунтувалася на реалістичних устремліннях, властивих вітчизняному мистецтву сучасної композитору доби. Саме установка на об’єктивне відображення всіляких сторін життя, як «відтворення типових характерів у типових обставинах» при збереженні їх індивідуально-психологічних рис, вірогідність зображення образів «у формах самого життя» були тим ідейнотематичним стрижнем, навколо якого в ХІХ столітті групувалися творчі інтереси М. Гоголя й Ф. Достоєвського, художників-передвижників, О. Даргомижського, самого М. Мусоргського й багатьох інших. Вибір предметів звичайних i, зокрема, звичайних, «не одягнених у геройську робу» персонажів - найважливіша тенденція мистецтва XIX століття. Однак прагнення до «звичайного», правдивого зображення життя «як вона є» позначилося не тільки у виборі сюжетів і героїв. У літературі й поезії воно знайшло відбиття в самому словесному втіленні - у лексиці, синтаксисі; у живопису - у техніці композиції й нових прийомах письма; у музиці ж, і особливо у музиці зі словом - у концепційному ускладненні способів музичного інтонування, у деталізованому, «портретно» укрупненому музичному вираженні образу [4].

Для М. Мусоргського слово було не тільки частиною мовлення й написаного тексту, але й невід'ємним компонентом мови, причому такої, що реально звучить, розгортається в часі. Тому для Мусоргського найважливішим художнім завданням в сфері музичного мовлення й мови, завданням, що випливає з вибору певних тем, сюжетів і образів, виявилася ідея втілення живої людської розмови, тому що інтонаційна іiї сторона здатна розкривати емоційну палітру почуттів, психологічний склад, душу й характер персонажа. 
Це прагнення, у свою чергу, було сполучено з необхідністю зафіксувати властивий тому або іншому персонажу тип, спосіб інтонування - ту даність, що перебуває в прямій залежності від соціальносуспільного статусу персонажа (точніше, його прообразу), від його походження, умов буття й т. ін. Але природність і правдивість інтонації, яка розуміється в цьому випадку як відповідність ритмо-звуковисотних параметрів музичного еквівалента реальному людському мовленню, виявилися в Мусоргського не стільки в більшій схильності до речитативного начала, аніж до кантиленного, скільки в загальній установці на розширення музично-інтонаційного, зокрема речитативного словника за рахунок розширення спектра його взаємодії 3 вербальним началом, з усним словом - словесною мовою.

На шляху подібного роду шукань М. Мусоргський в 60 -ті роки не був самотнім. «Великим вчителем життєвої правди» для композитора став його старший сучасник О. Даргомижський, знайомство з яким відбулося в 1856 році. Обох ріднила загальна художня мета й прагнення знайти ті засоби, які найбільшою мірою сприяли б іiі досягненню. У зв’язку з цим згадаємо відому думку О. Даргомижського, висловлену ним в одному з листів, думку, що чітко формулює естетичне credo композитора: «Прагну, щоб звук прямо виражав слово. Прагну правди!» И хоча ці широко відомі слова прокоментовані дослідниками творчості композитора неодноразово, варто ще раз загострити на них увагу.

3 одного боку, вкладений у них зміст став основою для художніх пошуків М. Мусоргського, а з іншого - важливо уточнити, що ховається за словом «правда» і чи однаково розуміли для себе форму iï втілення обидва композитори. У висловленні О. Даргомижського під «правдою» мається на увазі, насамперед, відбиття людського характеру з усією можливою психологічною, а іноді й соціальною конкретністю. I досягнення іiі Даргомижський бачив у максимально точній музичній імітації мовного інтонування - у передачі його звуковисотного малюнку (див., наприклад, романси «Титулярний радник», «Мірошник», «Черв’як»). Від цієї позиції відштовхувався в другій половині 60-х років і Мусоргський, коли створював пісні-портрети «Светик Савишна» (1866), «Семінарист» (1866), «Бешкетник» (1867), «Сиротка» (1868), «Колискова Срьомушці» (1868) і «3 нянькою» (1868), що безпосередньо передують роботі над «Одруженням». Звідси ж ведуть своє походження й перші висловлення композитора про «говір людський» [1;5]. 
Для творчої еволюції Мусоргського поворот до «Одруження» в 60-ті роки був закономірним. Потрібно віддати тут належне сміливості й естетичній далекоглядності, з якими Мусоргський взявся за створення опери на незмінений прозаїчний, притому повсякденного типу прозаїчний текст - на матеріал, зовсім невідповідний традиційним вимогам оперного лібрето. Завдяки своєму своєрідному естетичному експерименту Мусоргський став першим, хто в історичному розвитку музики виявив перспективи створення нового типу концепції, заснованої на синтезі власне музичної драматургії із глибинним запровадженням специфічних прийомів прозаїчного оповідання до музичної концепції. І в цьому сенсі композитор історично просунувся набагато далі своїх сучасників, перевершивши в «правдивості» знайденої ним мови вираження навіть свого безпосереднього натхненника О. Даргомижського, який у межах оперного жанру до прози звертався лише в силабічних речитативних епізодах.

Увесь шлях, пройдений М. Мусоргським, від ранніх вокальних мініатюр до пісень кінця 60 -х років, є шляхом інтуїтивного руху до прози: у змістовному аспекті - до «прози життя», а в мовно-структурному - до опори на публічно-словесні жанри, до опери-речитативу, що послужила стимулом для подальшого пошуку форм музичного втілення «людських голосових інтонацій» у вокальній творчості 70-х.

Камерно-вокальна музика в різних варіантах її внутрішніх жанрових можливостей стала необхідною основою творчого методу композитора (тобто і оперного також) тому, що припускала послідовну аналітичну роботу зі словом, пошук шляхів взаємодії поетичного та музичного художньо-виразових рядів, а також сприяла розвитку психологічно-характерологічних засобів музики, які є необхідними для створення музичної типології людських характерів. Саме в напрямку такої типології й вибудовується романтична опера.

Близький О. Даргомижському за складом свого таланту, М. Мусоргський примикає до нього й за поглядами на музичну драму (музичну трагедію), навіяними на нього оперою Даргомижського «Кам'яний гість». Однак, на відміну від Даргомижського, у своїх зрілих творах Мусоргський, по-перше, прагне до більших історичних масштабів оперного задуму, по-друге, зберігає вірність головному музичному - оперному - «герою»: народу, який він «розуміє як єдину особистість», віддану великій ідеї, натхнену ідеєю. Усі діючі особи опер Мусоргського є персоніфікаціями цієї ідеї з різних її сторін, різними її іпостасями. 
Щоб підкреслити цю жанрову особливість опери «Хованщина», як саме новаторську, Мусоргський дав їй авторський словесний підзаголовок «народна музична драма». У роботі над «Хованщиною» композитор виявляється вже не тільки лібретистом, але й сучасним письменником-істориком, археографом і соціологом одночасно. Завершена панорама людських характерів, яку композитор представляє в опері, виникає спільним словесно-музичним шляхом. Вона дозволяє оцінити метод Мусоргського як поліфонічний, що не поступається за психологічною проникливістю романній поетиці Ф. Достоєвського. Продовжуючи напрям «історичної трагедії», початий в «Борисі Годунові», «Хованщина» розроблює далі й пушкінську тему у творчості М. Мусоргського: композитору вдається сприйняти й продовжити літературні шукання О. Пушкіна, у тому числі стосовно стильової свободи поетичного тексту. Як зауважує $Є$. Фрід, «в «Хованщині» знайшли переважний розвиток принципи пушкінської хронікальної драматургії» $[5,117]$. Однак це виражається не стільки в децентралізації діючих осіб (у поліцентричності персонажів), скільки в розкритті недосконалості, насамперед моральної, як самої людини, так і соціального механізму iii життя. Саме О. Пушкін відкрив галерею тих образів у російській літературі, які цікаві своїми недоліками, негативними рисами, «втечею від ідеалізації». У російській оперній творчості романтичного періоду тільки М. Мусоргський зумів підтримати цей тип художнього характеру і знайти відповідні до нього засоби музичної виразовості.

В операх «Борис Годунов» і «Хованщина» зустрічаються всі види оперних номерів. Структура їх відрізняється різноманітністю - від тричастинності (арія Шакловитого) до величезних вільно-речитативних сцен (монолог Бориса в сцені з курантами). У кожній новій опері Мусоргський використовує ансамблі й хор усе частіше; в «Хованщині», написаній після «Бориса Годунова», чотирнадцять хорів, що дає підставу називати іiі «хоровою оперою».

В операх Мусоргського відносно мало закінчених арій і незрівнянно більше аріозо - тобто невеликих і глибоко емоційних музичних характеристик персонажів. Важливого значення набувають арія-розповідь і побутові вокальні форми, органічно пов'язані із драматургією цілого, а також монологи, у яких словесний текст визначає й направляє музичну побудову. Працюючи над «говором людським», композитор відкривав нову зацікавленість в мелодії, що діється цим говором, до наближення речитативу та оперної мелодії, до нового типу оперної кантилени як «осмисленої/виправданої мелодії», як пи- 
сав М. Мусоргський В. Стасову, створюючи новий стиль вокального письма, що є результатом численних експериментів і устремлінь усього його творчого життя [3]. Вершиною й підсумком шукань у цій області була партія Марфи з опери «Хованщина». Саме в цій партії композитор досяг «найбільшого синтезу» мовленєєвої виразовості зі справжнім мелодизмом [5].

Таким чином, близькість до вербальної основи літературної мови, загострення всіх засобів виразовості прозаїчного мовлення у творчості М. Мусоргського виявилися солідарними з його прагненням розкрити протиріччя людського життя як не випадкові, обумовлені всією людською історією, пояснити зміст російської історії як приреченості на розкол і двосвітність. Монологічність форми у взаємодії 3 принципами наскрізного розвитку, відмова від традиційних лейтмотивів заради посилення моноінтонаційних зв'язків у музичній еволюції образу, індивідуалізація характерів і виявлення їх динамічності за допомогою стилістично деталізованого музичного письма - ці принципи оперної творчості М. Мусоргського безпосередньо пов'язані 3 його ставленням до слова, «життєво-правдивих» вербальних аспектів та літературно-поетичних можливостей смислового синтезу.

У цілому наукова новизна дослідження обумовлена запровадженням нових жанрових та мовно-мовленнєвих критеріїв вивчення оперної мови, що дозволяють визначати синтетичні форми оперних сольно-вокальних лексикодів, зокрема у творчості М. Мусоргського. Висновки роботи вказують, по-перше, на провідне значення у розвитку оперної вокальної мови впливу жанрів словесності, пов'язаних 3 риторичною практикою та провідними комунікативними життєво-повсякденними сферами, по-друге, на ті новаторські досягнення М. Мусоргського, які позначили подальший розвиток музичної мови опери як синтетичної за сумісними зі словесними жанровими витоками.

\section{СПИСОК ЛІТЕРАТУРИ}

1. Васина-Гроссман В. Русский классический романс XIX столетия. М.: Изд-в АН СССР, 1956. 352 с.

2. Лихачев Д. Поэтика древнерусской литературы. М.: Наука, 1979. 352 с.

3. Мусоргский М. Письма. М.: Музыка, 1981. 359 с.

4. Оголевец А. Слово и музыка в вокально-драматических жанрах. М.: Музгиз, 1960. 523 с.

5. Фрид Е. М. П. Мусоргский. Проблемы творчества: исследование. Л.: Музыка, 1981. 184 с. 
6. Хубов Г. Мусоргский. М.: Музыка, 1969. 803 с.

7. Чистякова И. О жанрах российской словесности. URL: http://asu.edu. ru/images/File/Publikatzii/O_Zhanrakh.pdf

\section{REFERENCES}

1. Vasina-Grossman, (1956). V. Russian classic romance XIX century. M.: Publishing House of the Academy of Sciences of the USSR [in Russian].

2. Likhachev, D. (1981). Poetics of ancient Russian literature. M.: Nauka, 1979. [in Russian].

3. Mussorgsky, M. (1981). Letters. M.: Music [in Russian].

4. Ogolevets, A. (1960). Word and music in vocal and dramatic genres. M.: Muzgiz [in Russian].

5. Fried, E. (1981). M. P. Mussorgsky. Problems of creativity: Research. L.: Music [in Russian].

6. Hubov, G. (1969). Mussorgsky. M.: Music [in Russian].

7. Chistyakova I. On the genres of Russian literature. URL: http://asu.edu.ru/ images/File/Publikatzii/O_Zhanrakh.pdf. [in Russian].

Стаття надійщла до редакції 13.12.2017

УДК 78.03/03.1+786.2

DOI $10.31723 / 2524-0447-2018-26-74-86$

Хе Веньлі

https://orcid.org/0000-0002-4315-3379

здобувач кафедри історії музики

та музичної етнографії

ОНМА ім. А. В. Нежданової

OdHeWenli@gmail.com

\section{МЕЛОДИЧНІ ЗАСАДИ ФОРТЕПІАННОГО СТИЛЮ Ф. ШОПЕНА: АКТУАЛЬНІ МУЗИКОЗНАВЧІ ПІДХОДИ}

Метою статті є інтегративне представлення музикознавчих підходів до мелодійної парадигми фортепіанної творчості Ф. Шопена як до стильової, відтак когнітивно-мовної. Методологія роботи утворюється перетином історіографічного та жанрово-стильового методів вивчення фортепіанної спадщини композиторів-романтиків. Наукова новизна дослідження зумовлена підходом до мелодичності музичного тексту та мелодійного змісту фортепіанних творів Шопена як явищ стильового походження, пов'язаних не лише з природою інструмента, а й з музично-образним мисленням композитора та притаманними йому засобами музичного мовлення. Висновки статті засвідчують, що в творчості 